\title{
KUALITAS PELAYANAN BANK DENGAN MENGGUNAKAN METODE IMPORTANCE PERFORMANCE ANALYSIS (IPA) DAN CUSTOMER SATISFACTION INDEX (CSI) TERHADAP KEPUASAN NASABAH
}

\author{
Yudi Siyamto \\ STIE-AAS Surakarta \\ Email: yudi.siyamto@yahoo.com
}

\begin{abstract}
Abstrak
The purpose of this study was to determine the quality of services provided by the bank in serving kepusan customers using 5 dimensions of assurance, reliability, tangibility, empathy, and responsiveness, so from that dimension is unknown dimension into the client's preferences into consideration the quality of services by banks in Surakarta. The method used is the Importance Performance Analysis (IPA) and the Customer Satisfaction Index (CSI) doped with Miscrosoft software Excel for Windows and SPSS for windows. Questionnaires distributed amounted to 90 respondents with a sampling with accidental sampling method. The results of data processing by using IPA (Importance Performance Analysis) obtained an average rate of $95.21 \%$ suitability. Furthermore, for the assessment of the quadrant where the priority that should be corrected is related Equanimity customers and Ease of providing services. However the overall services provided by the bank are quite satisfied because of the 20 attributes, only the second to be prioritized. It was also evident from the results of the methods CSI (Customer Satisfaction Index) indicates the level of customer satisfaction by $80.80 \%$. The value is in the range from 66 to $80.99 \%$, so overall customers are satisfied with the performance of the services provided by the bank in Surakarta.
\end{abstract}

Keywords: Service Quality, Importance Perormance Analysis (IPA), Customer Satisfaction Index (CSI), Customer Satisfaction

\section{Pendahuluan}

Dalam menjalankan setiap tugasnya perbankan membutuhkan kepercayaan dari nasabah karena salah satu fungsi perbankan adalah sebagai lembaga intermediasi. Sehingga untuk memperoleh kepercayaan tersebut maka perbankan harus dapat bekerja secara profesional sesuai dengan yang diharapkan oleh nasabah mulai dari segi keuangan, segi pelayanan, dan strategi pemasaran harus dikelola dengan baik, serta perbankan juga harus semakin kreatif dalam menghasilkan produk-produk terbaru yang diinginkan masyarakat atau nasabahnya.

Otoritas jasa keuangan dalam data statistik perbankan Indonesia, menyatakan JURNAL ILMIAH EKONOMI ISLAM VOL. 03 NO. 01, MARET 2017 bahwa perkembangan perbankan di Indonesia sampai dengan bulan November 2014 tercatat jumlah bank umum yang berdiri sebanyak 119 dengan jumlah kantor sebanyak 19.780 bank, sedangkan pada buan Desember 2015 menjadi 118 bank dengan jumlah kantor sebanyak 32.963. Hal ini mengalami penurunan dari sejak tahun tahun 2013 yaitu sebanyak 120 bank. $^{1}$

Melihat perkembangan perbankan saat ini membawa dampak pada perdagangan bebas yang terjadi, dimana hal ini mengakibatkan setiap perusahaan harus menghadapi persaingan yang ketat.

\footnotetext{
${ }^{1}$ Statistik Perbankan Indonesia - Vol. 14, No. 1, Desember 2015
} 
Meningkatnya intensitas persaingan dan jumlah pesaing, menuntut perusahaan untuk selalu memperhatikan kebutuhan dan keinginan pelanggan serta berusaha memenuhi harapan pelanggan dengan cara memberikan pelayanan yang lebih memuaskan dari pada yang dilakukan oleh pesaing.

Tho'in (2016) menyatakan bahwa jika melihat dan mencermati dalam kurun waktu tahun 2013 sampai tahun 2015 atau yang sering disebut fase ke empat pertumbuhan bank syariah, di mana antara perkembangan jaringan usaha syariah atau kantor perbankan dengan perkembangan aset menunjukkan hasil yang tidak sesuai targettarget yang diharapkan. $^{2}$

Hasan (2010) menyatakan bahwa tujuan dari setiap bisnis adalah untuk menciptakan kepuasan para pelanggan. Kualitas jasa yang unggul dan konsisten dapat menumbuhkan kepuasan pelanggan dan akan memberikan berbagai manfaat. $^{3}$

Kepuasan pelanggan merupakan salah satu kunci sukses lembaga keuangan dalam jangka panjang. Apabila pelanggan merasa puas dengan kualitas jasa yang diberikan, kemungkinan besar pelanggan akan menceritakan hal-hal yang positif kepada orang lain mengenai lembaga keuangan tersebut. Sebaliknya jika pelanggan merasa tidak puas, maka mereka kecenderungan akan mengeluh, menceritakan pengalaman buruknya kepada orang lain serta mereka dapat menggugat lembaga keuangan. Sejalan dengan pendapat tersebut Barlow dalam

\footnotetext{
2 Tho'in, Muhammad. 2016. Kompetensi Sumber Daya Manusia Bank Syariah Berdasarkan Prinsip-Prinsip Syariah Islam. Jurnal Ilmiah Ekonomi Islam Vol 02, No. 03. Hal. 159.

${ }^{3}$ Hasan, Ali. 2010. "Marketing Bank Syariah Cara Jitu Meningkatkan Pertumbuhan Pasar Bank Syariah". Ghalia Indonesia. Bogor.
}

JURNAL ILMIAH EKONOMI ISLAM VOL. 03 NO. 01, MARET 2017
Raharso menyatakan bahwa keluhan adalah hadiah dari pelanggan, bukan suatu ancaman. ${ }^{4}$ Pengukuran terhadap kualitas pelayanan perlu dilakukan untuk mendapatkan peningkatan kualitas pelayanan dan evaluasi sehingga instansi tersebut memiliki pelanggan yang setia. Apabila pemberian kualitas pelayanan yang buruk dapat membuat pelanggan semakin kecewa dan citra instansi tersebut berkurang di mata pelanggan. $^{5}$

Terdapat beberapa cara untuk mengukur tentang kualitas pelayanan, salah satu cara untuk mengukur kualitas pelayanan adalah dengan menerapkan metode Importance Performance Analysis (Analisis Kepentingan dan Kinerja). Metode analisis yang digunakan adalah analisis kuadran. Analisis kuadran ini digunakan untuk mengetahui respon konsumen terhadap atribut yang diplotkan berdasarkan tingkat kepentingan dan kinerja dari masing-masing atribut tersebut. Berdasarkan analisis kuadran ini selanjutnya dapat dilihat letak dari masingmasing variabel berada pada kuadran yang berbeda-beda, sehingga dapat diketahui variabel apa saja yang perlu ditingkatkan dan mendapatkan perhatian lebih.

Kemudian Aritonang

menyatakan untuk mengukur Kepuasan pelanggan secara keseluruhan dapat diukur menggunakan Customer Satisfaction Index (CSI). Untuk menciptakan nilai kepuasan bagi

\footnotetext{
${ }^{4}$ Maulana, Yassyir, dkk. 2012. "Analisis Pengaruh Servqual Terhadap Kepuasan Serta Loyalitas Mahasiswa (Studi Kasus Pada Jurusan Teknik Mesin Di Universitas "XYZ")". Jurnal Miller, Cyndee 1993. "Moving Production to Services". New Jersey: Englewood Prentice-Hall, Inc. Rekayasa Mesin Vol.3, No. 1 Tahun $2012: 258-267$

${ }^{5}$ Azzahra Handriati, Annisa., dkk, 2015, "Analisis Kualitas Pelayanan Publik Terhadap Kepuasan Konsumen Dengan Menggunakan Metode Servperf-Ipa-Csi", Teknoin Vol. 21 No. 4 Desember 2015 : 178-190
} 
pelanggan dalam usaha pengendalian kualitas jasa, ada lima dimensi kualitas yang menjadi fokus pada kualitas pelayanan yaitu tangibles (bukti fisik), reliability (keandalan), responsiveness (daya tanggap), assurance (jaminan), emphaty (empati). ${ }^{6}$

Berdasarkan uraian di atas tujuan dilakukan penelitian ini adalah untuk mengetahui bagaimana kualitas pelayanan yang diberikan oleh pihak bank dalam melayani kepusan nasabah dengan menggunakan 5 dimensi yaitu assurance, reliability, tangibility, empathy, dan responsiveness, sehingga dari dimensi tersebut akan diketahui dimensi yang menjadi preferensi nasabah dalam mempertimbangkan kualitas pelayanan oleh bank di Kota Surakarta.

\section{Kajian Pustaka}

\section{Kualitas Jasa}

Agar pelayanan yang diberikan dapat berkualitas baik dan dapat memberikan kepuasan pada konsumennya maka sebaiknya perusahaan perlu memperhatikan berbagai dimensi yang bisa menciptakan dan meningkatkan kualitas pelayanan.

Dalam kehidupan sehari-hari seringkali kita mendengar orang membicarakan masalah kualitas, misalnya mengenai kualitas sebagian besar produk bauran luar negeri yang lebih baik dari pada dalam negeri. Definisi-definisi kualitas adalah merupakan usaha perusahaan untuk menunjukkan bahwa setiap orang memerlukan definisi operasional mengenai kualitas. Definisi operasional merupakan deskripsi dalam ukuran-ukuran yang

\footnotetext{
${ }^{6}$ Husna Ainu Syukri, Siti., 2014, "Penerapan Customer Satisfaction Index (Csi) Dan Analisis Gap Pada Kualitas Pelayanan Trans Jogja", Jurnal Ilmiah Teknik Industri, Vol. 13, No. 2, Des 2014
}

JURNAL ILMIAH EKONOMI ISLAM VOL. 03 NO. 01, MARET 2017 dikuantifikasikan mengenai apa yang diukur dan langkah-langkah yang perlu dilakukan untuk mengukurnya secara konsisten. Tujuan pengukuran ini adalah untuk menentukan kinerja aktual proses tersebut. ${ }^{7}$ Meskipun tidak ada definisi mengenai kualitas yang diterima secara universal, dimana dalam pengertian kualitas terdapat elemen-elemen yaitu sebagai berikut:

1) Kualitas meliputi usaha memenuhi atau melebihi harapan pelanggan.

2) Kualitas mencakup produk jasa, manusia, proses, dan lingkungan.

3) Kualitas merupakan kondisi yang selalu berubah

Berdasarkan elemen-elemen tersebut, Goetsh dan Davis (1994) membuat definisi bahwa kualitas merupakan suatu kondisi dinamis yang berhubungan dengan produk, jasa, manusia, proses, dan lingkungan yang memenuhi atau melebihi harapan ${ }^{8}$. Lewis dan Booms (1983) yang dikutip dalam oleh Tjiptono (1997), kualitas jasa adalah ukuran seberapa bagus tingkat layanan yang diberikan mampu sesuai dengan ekspektasi pelanggan ${ }^{9}$.

Menurut Tho'in (2011) kualitas jasa menjadi suatu item penting yang harus diperhatikan di dunia perbankan. ${ }^{10}$ Agar pelayanan yang diberikan dapat berkualitas baik dan dapat memberikan kepuasan pada konsumennya maka sebaiknya perusahaan perlu memperhatikan berbagai dimensi yang

\footnotetext{
7 Tjiptono, Fandy 2000. "Prinsip-prinsip Total Quaiity Service". CV. Andi Offset.Yogyakarta. hlm. 12-13

8 Tjiptono, Fandy dan Anastasia Diana. 1998. "Total Quality Management". Andi. Yogyakarta. Hlm. 3-4

9 Wijaya, Tony. 2011. "Manajemen Kualitas Jasa". Indeks. Jakarta. Hlm. 152

10 Tho'in, Muhammad. 2011. Pengaruh Faktor-faktor Kualitas Jasa terhadap Kepuasan Nasabah di Baitul Maal wat Tamwil (BMT) Tekun Karanggede Boyolali. Muqtasid Jurnal Ekonomi dan Perbankan Syariah STAIN Salatiga. Vol. 2, Nomer 1. Salatiga. Hlm 75.
} 
bisa menciptakan dan meningkatkan kualitas pelayanan.

Perkembangan terakhir ditemukan bahwa Zeithaml dalam Lesmana mengemukakan bahwa dimensi yang dianalisis untuk kepuasan nasabah dapat ditentukan dalam lima dimensi yang sebelumnya adalah sepuluh dimensi, dimana kelima dimensi kualitas jasa yaitu : tangibility, reliability, responsiveness, assurance, dan empathy. Adapun penjelasannya dalam Tjiptono dan Diana (1998) adalah sebagai berikut: ${ }^{11}$

1. Bukti Langsung (Tangibles), bukti secara fisik yaitu bukti yang ditunjukkan oleh fasilitas fisik, peralatan yang digunakan, penampilan para karyawan penyaji jasa material dan sarana komunikasi.

2. Kehandalan (Reliability), yaitu menyajikan jasa sesuai dengan janji serta akurat dan memuaskan.

3. Daya Tanggap (Responsiveness), yaitu ketersediaan para karyawan untuk membantu pelanggan dan menyajikan jasa dengan segera.

4. Jaminan (Assurance), yaitu pengetahuan, ketrampilan dan kemampuan serta sopan santun karyawan dalam menyajikan jasa, aman dari bahaya, resiko, keraguan, serta memiliki sifat dapat dipercaya.

5. Empaty, meliputi kemudahan dalam berinteraksi, komunikasi yang baik, memberikan perhatian secara pribadi serta memahami kebutuhan dan keinginan pelanggan.

Selanjutnya menurut Parasuraman, et al., (1990) Terdapat dua faktor utama yang mempengaruhi kualitas jasa, yaitu expected service dan perceived service. Apabila jasa

\footnotetext{
11 Tjiptono, Fandy dan Anastasia Diana. 1998. Opcit. Hlm. 27-28

JURNAL ILMIAH EKONOMI ISLAM VOL. 03 NO. 01, MARET 2017
}

yang diterima atau dirasakan (perceived service) sesuai dengan yang diharapkan, maka kualitas jasa dipersepsikan baik dan memuaskan. Jika jasa yang diterima melampaui harapan pelanggan (expected service), maka kualitas jasa dipersepsikan sebagai kualitas yang ideal. Sebaliknya jika jasa yang diterima lebih rendah daripada yang diharapkan, maka kualitas jasa dipersepsikan buruk. Dengan demikian baik tidaknya kualitas jasa tergantung pada kemampuan penyedia jasa dalam memenuhi harapan pelangan secara konsisten ${ }^{12}$.

\section{Importance Performance Analysis (IPA)}

Menurut Tjiptono (2011) teknik ini dikemukakan pertama kali oleh Martilla dan James pada tahun 1977 dalam artikel mereka "Importance Performance Analysis" yang dipublikasikan di Journal of Marketing. Pada teknik ini, responden diminta untuk menilai tingkat kepentingan dan kinerja perusahaan, kemudian nilai rata-rata tingkat kepentingan dan kinerja tersebut dianalisis pada Importance-Performance Matrix, yang mana sumbu x mewakili persepsi sedangkan sumbu y mewakili harapan. Maka nanti akan didapat hasil berupa empat kuadran sesuai gambar berikut $^{13}$ :

12 Harish, M. Azka, et, al.,. 2014. "Usulan Perbaikan Kualitas Pelayanan Menggunkan Dimensi Banking Service Quality dengan Metode Service Quality (Studi Kasus di Bank X)". Jurnal Online Institut Teknologi Nasional. No. 04. Vol. 2. Hlm. 121-131

${ }^{13}$ Oscar Ong, Johan dan Pambudi, Jati.2014. "Analisis Kepuasan Pelanggan Dengan Importance Performance Analysis Di Sbu Laboratory Cibitung Pt Sucofindo (Persero)". Undip, Vol IX, No 1, Januari 2014 


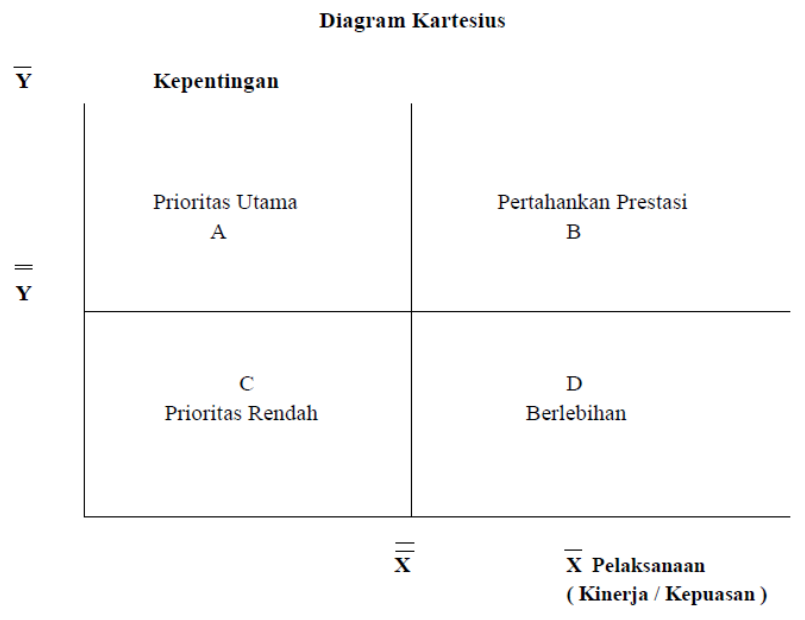

Adapun interpretasi dari kuadran tersebuat adalah sebagai berikut:

\section{A. Prioritas Utama (Concentrate Here)}

Pada kuadaran ini terdapat faktor-faktor yang dianggap penting dan atau diharapkan konsumen akan tetapi kinerja perusahaan dinilai belum memuaskan sehingga pihak perusahaan perlu berkonsentrasi untuk mengalokasikan sumber dayanya guna meningkatkan performa yang masuk pada kuadran ini.

B. Pertahankan Prestasi (Keep Up The Good Work)

Pada kuadaran ini terdapat faktor-faktor yang dianggap penting dan diharapkan sebagai faktor penunjang kepuasan konsumen sehingga perusahaan wajib untuk mempertahankan prestasi kinerja tersebut.

C. Prioritas Rendah (Low Priority)

Pada kuadaran ini terdapat faktor-faktor yang dianggap mempunyai tingkat persepsi atau kinerja aktual yang rendah dan tidak terlalu penting dan atau tidak terlalu diharapkan oleh konsumen sehingga perusahaan tidak perlu memprioritaskan atau memberikan perhatian lebih pada faktor-faktor tersebut.

D. Berlebihan (Possibly Overkill)
Pada kuadaran ini terdapat faktor-faktor yang dianggap tidak terlalu penting dan tidak terlalu diharapkan oleh pelanggan sehingga perusahaan lebih baik mengalokasikan sumber daya yang terkait pada faktor tersebut kepada factor lain yang lebih memiliki tingkat prioritas lebih tinggi.

\section{Customer Satisfaction Index (CSI)}

Customer Satisfaction Index (CSI) merupakan analisis kuantitatif berupa persentase pengguna yang senang dalam suatu survei kepuasan pengguna. CSI diperlukan untuk mengetahui tingkat kepuasan pengguna secara menyeluruh dengan memperhatikan tingkat kepentingan dari atribut-atribut produk atau jasa.

Perhitungan keseluruhan CSI menurut Bhote (1996) dalam Indra Maiyanti, Sri., dkk menyatakan bahwa nilai rata-rata pada kolom kepentingan (I) dijumlahkan sehingga diperoleh $\mathrm{Y}$ dan juga hasil kali I dengan $\mathrm{P}$ pada kolom skor (S) dijumlahkan dan diperoleh T. IKP diperoleh dari perhitungan (T/5Y) x 100\%. Nilai 5 (pada 5Y) adalah nilai maksimum yang digunakan pada skala pengukuran. Nilai maksimum IKP adalah 100\%. Nilai IKP 50\% atau lebih rendah menandakan kinerja pelayanan yang kurang 
baik. Nilai IKP $80 \%$ atau lebih tinggi mengindikasikan pengguna merasa puas terhadap kinerja pelayanan ${ }^{14}$.

Menurut Fitriana, et.al (2014) mengatakan bahwa Customer Satisfaction Index diperlukan karena proses pengukuran kepuasan pelanggan bersifat kontinu. Nilai CSI dalam penelitian ini dibagi menjadi 5 kategori mulai dari tidak puas sampai dengan sangat puas, berikut ini 5 kategori tersebut ${ }^{15}$ : Skala Customer Satisfaction Indeks (CSI)

\begin{tabular}{|l|l|l|}
\hline NO & Nilai Index & Keterangan \\
\hline 1 & $81 \%-100 \%$ & Sangat Puas \\
\hline 2 & $66 \%-$ & Puas \\
& $80,99 \%$ & \\
\hline 3 & $\begin{array}{l}51 \%- \\
65,99 \%\end{array}$ & Cukup Puas \\
\hline 4 & $\begin{array}{l}35 \%- \\
50,99 \%\end{array}$ & Kurang Puas \\
\hline 5 & $0 \%-34,99 \%$ & Tidak Puas \\
\hline
\end{tabular}

Sumber: Fitriana, et.al (2014:287)

\section{Kepuasan Nasabah}

Kualitas diperlukan dalam penyediaan produk atau jasa kepada pelanggan. Produk yang berkualitas adalah produk yang memiliki spesifikasi yang sesuai dengan kebutuhan konsumen sehingga menyebabkan konsumen merasa puas. Bagi perusahaan yang bergerak di bidang jasa, memuaskan kebutuhan pelanggan berarti perusahaan harus memberikan pelayanan berkualitas (service quality) kepada pelanggannya ${ }^{16}$.

\section{Kemudian Hartanto} menyatakan bahwa kepuasan pelanggan (nasabah) sebenarnya masih bersifat abstrak.

\footnotetext{
14 Indra Maiyanti, Sri., Irmeilyana,Verawaty, "Aplied Customer Satisfaction Index (CSI) and ImportancePerformance Analysis (IPA) to know

Student Satisfaction Level of Sriwijaya University Library Services".

15 Fitriana, Dewi et.al., 2014, "Pengukuran Kepuasan Kontraktor Terhadap Kinerja Klien Pada Proyek Kontruksi Swasta", Jurnal Karya Teknik Sipil, Vol. 3, No.1, Tahun 2014, Hal: 283-295
}

16 Wijaya, Tony. 2011, Opcit. Hlm. 152

JURNAL ILMIAH EKONOMI ISLAM VOL. 03 NO. 01, MARET 2017
Pencapaian kepuasan dapat merupakan proses yang sederhana, kompleks ataupun rumit. Dalam hal ini peranan setiap individu dalam service encounter sangatlah penting dan berpengaruh terhadap kepuasan yang dibentuk $^{17}$.

Kepuasan atau ketidakpuasan adalah perasaan senang atau kecewa seseorang yang berasal dari perbandingan antara kesannya terhadap kinerja produk riil atau aktual dengan kinerja produk yang diharapkan ${ }^{18}$. Kotler (2006) dalam Wijaya (2011), mendefinisikan kepuasan pelanggan adalah tingkat perasaan seseorang setelah membandingkan kinerja (hasil) yang ia rasakan dibandingkan dengan harapannya. Pendapat lain yaitu Robledo (2001) dalam Astuti (2009) menyatakan bahwa kepuasan pelanggan didefinisikan sebagai selisih $(g a b)$ antara persepsi dan harapan konsumen ${ }^{19}$, kemudian Dharmayanti (2006) kepuasan nasabah adalah perasaan pelanggan saat menerima dan setelah merasakan pelayanan bank $^{20}$. Sehingga kriteria kepuasan yang ditinjau dari pendapat Robledo (2001) dalam Astuti (2009), menyatakan bahwa konsumen atau nasabah akan memiliki persepsi positif apabila penyedia jasa memenuhi atau melebihi apa yang diharapkan konsumen ${ }^{21}$.

17 Hartanto, Juzan Tri. 2010. "Analisis Pengaruh Kualitas Pelayanan Jasa Perbankan Terhadap Kepuasan Nasabah (Study Kasus Pada PD. BPR Bank Jogja)". Program Magister Manajemen Universitas Gunadarma

${ }^{18}$ Sangadji, Etta Mamang dan Sopiah. 2013. "Perilaku konsumen". CV. Andi Offset. Yogyakarta. Hlm. 180

${ }^{19}$ Astuti, Septin Puji, et, al.,, 2009, "Meningkatkan Kualitas Pelayanan di Bank Syariah; Penelitian dengan Fuzzy Servqual dan Dimensi Carter", Jurnal Manajemen Bisnis Vol. 2 No. 1 April-Juli 2009 (47-58).

20 Dharmayanti, Diah. 2006. "Analisis Dampak Service Performance Dan Kepuasan Sebagai Moderating Variable Terhadap Loyalitas Nasabah". Jurnal Manajemen Pemasaran, Vol. 1, No. 1, April 2006: $35-43$

21 Astuti, Septin Puji, et, al.,, 2009, Opcit. 


\section{Pengukuran kepuasan pelanggan} menurut Kotler dalam Wijaya (2011), mengidentifikasikan menjadi empat metode yaitu sebagai berikut:

1) Sistem keluhan dan saran

Setiap organisasi yang berorientasi pada pelanggan (customer oriented) perlu memberikan kesempatan yang luas kepada para pelangganya untuk menyampaikan saran, pendapat, dan keluhan mereka. Dalam sistem ini media digunakan bisa berupa kotak saran yang ditempatkan di lokasi-lokasi stategis, saluran telepon bebas pulsa, website, dll. Berdasarkan karateristiknya, metode ini bersifat pasif, karena perusahaan menunggu inisiatif pelanggan untuk menyampaikan keluhan atau pendapat. Oleh karena itu, sulit mendapatkan gambaran lengkap mengenai kepuasan atau ketidakpuasan pelanggan mengenai cara ini.

\section{2) Ghost Shopping}

Salah satu cara untuk memperoleh gambaran mengenai kepuasan pelanggan adalah dengan memperkerjakan beberapa orang (ghost shooper) untuk berperan atau bersikap sebagai calon pelanggan atau pembeli produk perusahaan dan pesaing. Kemudian mereka melaporkan temuantemuannya mengenai kekuatan dan kelemahan produk perusahaan dan pesaing berdasarkan pengalaman mereka dalam pembelian produk-produk tersebut.

\section{3) Lost Customer analysis}

Metode ini dilakukan dengan cara menghubungi para pelanggan yang telah berhenti membeli atau telah pindah pemasok agar dapat memahami mengapa hal itu terjadi dan agar dapat mengambil kebijakan perbaikan atau penyempurnaan selanjutnya.
4) Survei kepuasan pelanggan

Melalui survei, perusahaan akan memperoleh tanggapan dan umpan balik (feedback) secara langsung dari pelanggan dan juga memberikan tanda (signal) positif bahwa perusahaan menaruh perhatiannya terhadap para pelanggannya.

Jadi penulis menyimpulkan bahwa kepuasan itu adalah perbandingan antara kinerja yang dirasakan dengan harapan. Apabila kinerja dibawah harapan maka pelanggan atau konsumen akan kecewa dan bila kinerja sesuai dengan harapan maka pelanggan atau konsumen akan puas dan bila kinerja melebihi harapan maka pelanggan atau konsumen merasa sangat puas.

Sehingga jika dikaitkan dengan perbankan dapat disimpulkan bahwa harapan dan persepsi mempengaruhi nasabah (pelanggan) dalam menentukan produk bank. Apabila pilihan atas produk yang ditawarkan sesuai dengan yang diharapkan nasabah, maka mereka akan merasa puas dan mereka semakin cenderung merasa nyaman terhadap bank karena dalam persepsinya sangat baik.

\section{Metode Penelitian}

Dalam penelitian ini jenis instrumen penelitian yang digunakan adalah metode angket (questionnaire). Jenis data yang digunakan adalah data kualitatif yang diangkakan berupa angket dan data kuantitatif. Untuk memperoleh jawaban berupa data kuantitatif untuk diolah secara statistik dengan menggunakan skala pengukuran yaitu skala likert.

Sedangkan kantor cabang Bank Mega, Bank BNI dan Bank Mandiri di Surakarta merupakan tempat dalam melakukan penelitian. Semua nasabah di wilayah Surakarta merupakan populasi. Sampel yang 
digunakan dalam penelitian yang dilakukan saat ini adalah dengan menggunakan metode accidental sampling.

\section{Metode Pengumpulan Data}

Sumber data dalam penelitian ini adalah jenis data primer. Data primer adalah data yang diperoleh atau dikumpulkan langsung dilapangan oleh orang yang melakukan penelitian atau yang bersangkutan yang memerlukannya $^{22}$. Jenis data primer yang digunakan dalam penelitian ini adalah berupa kuesioner yang diberikan kepada nasabah bank umum konvensional, dimana bank tersebut terdiri dari Bank Mega, Bank BNi, dan Bank Mandiri yang berada di Surakarta.

Adapun data sekunder yang digunakan dalam penelitian ini adalah untuk memperkuat landasan teori dan sebagai rujukan dalam mempelajari penelitian yang telah dilakukan sebelumnya.

\section{Metode Analisis Data}

Uji validitas dan reliabilitas digunakan dalam langkah awal penelitian ini, dimana Uji validitas dapat dilakukan dengan membandingkan nilai $r$ hitung (corrected item total correlation) dengan $\mathrm{r}$ tabelnya. Apabila nilai $r$ hitung $>r$ tabel dan nilai $r$ positif, maka butir atau pertanyaan tersebut dikatakan valid, Ghozali (2005). Sedangkan Uji reliabilitas adalah sesuatu instrumen cukup dapat dipercaya untuk digunakan sebagai alat pengumpul data karena instrumen tersebut sudah cukup baik. Uji reliabilitas dilakukan dengan menggunakan koefisien Cronbach Alpha. Menurut Ghozali (2005) Instrumen dapat dikatakan handal (reliable) bila mempunyai koefisien Cronbach alpha > 0,6.

\footnotetext{
${ }^{22}$ Hasan, M. Iqbal. 2002, "Pokok-Pokok Materi Metodologi Penelitian dan Aplikasinya", Cetakan Pertama, Ghalia Indonesia, Jakarta. Hlm. 82
}

JURNAL ILMIAH EKONOMI ISLAM VOL. 03 NO. 01, MARET 2017
Pengujian reliabilitas ini dilakukan dengan menggukan program SPSS 17 for Windows ${ }^{23}$.

Teknik analisis data yang digunakan dalam penelitian ini adalah menerapkan metode Important Performance Analysis yaitu dengan melakukan analisis kuadran untuk menunjukkan hubungan antara penilaian tingkat kepentingan dan tingkat kinerja. Tahapan dalam metode Importance Performance Analysis adalah berikut ${ }^{24}$ :

1. Perhitungan Tingkat Kesesuaian (TKi) antara tingkat kinerja dan harapan

2. Perhitungan rata-rata kinerja dan harapan seluruh pelanggan

3. Perhitungan rata-rata kinerja dan harapan seluruh atribut

4. Penjabaran tiap atribut disajikan dalam diagram kartesius yang dibagi menjadi empat kuadran dan dibatasi.

Selanjutnya analisa yang dilakukan adalah dengan menggunakan metode Customer Satisfaction Indeks (CSI) yang dilakukan dengan perhitungan sebagai berikut:

1. Menentukan Mean Importance Score (MIS) dan Mean Satisfaction Score (MSS)

2. Membuat weight factor (WF),

3. Membuat weighting score (WS)

4. Menentukan CSI

5. Nilai CSI dalam penelitian ini dibagi menjadi 5 kategori mulai dari tidak puas sampai dengan sangat puas.

\section{Hasil Penelitian dan Pembahasan Uji validitas dan reliabilitas}

Hasil dari pengujian validitas dan reabilitas yang telah diberikan sebanyak 90

\footnotetext{
${ }^{23}$ Ghozali, 2005. "Aplikasi Analisis Multivarariate Dengan Program SPSS". Badan Penerbit Universitas Diponegoro Semarang. Semarang. 24 Supranto, J. 1997. “Analisis Multivariat Arti dan Interpretasi”. Jakarta: Rineka Cipta
} 
kuesioner kepada nasabah bank berkaitan dengan keabsahan sebuah pernyataan dimana diketahui hasil uji reliabel instrumen pada

masing-masing variabel menunjukkan bahwa instrumen telah reliabel, dengan ditunjukkan pada tabel dibawah ini:

\begin{tabular}{|c|c|c|c|c|c|c|c|}
\hline Variabel & $\begin{array}{l}\text { Cronbach's } \\
\text { Alpha }\end{array}$ & Pengujian & Kesimpulan & $\begin{array}{l}\text { Variabel } \\
\text { Indikator }\end{array}$ & $\begin{array}{l}\text { Corrected } \\
\text { Item-Total } \\
\text { Correlation }\end{array}$ & Pengujian & $\underset{\mathrm{n}}{\text { Kesimpula }}$ \\
\hline \multirow{4}{*}{ Assurance } & \multirow{4}{*}{.769} & \multirow{4}{*}{$0,60-0,79$} & \multirow{4}{*}{ Diterima } & Q5 & .634 & 0,207 & Valid \\
\hline & & & & Q6 & .462 & 0,207 & Valid \\
\hline & & & & Q7 & .623 & 0,207 & Valid \\
\hline & & & & Q8 & .567 & 0,207 & Valid \\
\hline \multirow{4}{*}{ Reliability } & \multirow{4}{*}{.761} & \multirow{4}{*}{$0,60-0,79$} & \multirow{4}{*}{ Diterima } & Q9 & .567 & 0,207 & Valid \\
\hline & & & & Q10 & .643 & 0,207 & Valid \\
\hline & & & & Q11 & .571 & 0,207 & Valid \\
\hline & & & & Q12 & .472 & 0,207 & Valid \\
\hline \multirow{3}{*}{ Tangibility } & \multirow{3}{*}{.654} & \multirow{3}{*}{$0,60-0,79$} & \multirow{3}{*}{ Diterima } & Q13 & .429 & 0,207 & Valid \\
\hline & & & & Q14 & .620 & 0,207 & Valid \\
\hline & & & & Q15 & .370 & 0,207 & Valid \\
\hline \multirow{6}{*}{ Empathy } & \multirow{6}{*}{.865} & \multirow{6}{*}{$0,60-0,79$} & \multirow{6}{*}{$\begin{array}{c}\text { Reabilitas } \\
\text { Baik }\end{array}$} & Q16 & .600 & 0,207 & Valid \\
\hline & & & & Q17 & .636 & 0,207 & Valid \\
\hline & & & & Q18 & .703 & 0,207 & Valid \\
\hline & & & & Q19 & .655 & 0,207 & Valid \\
\hline & & & & Q20 & .744 & 0,207 & Valid \\
\hline & & & & $\mathrm{Q} 21$ & .627 & 0,207 & Valid \\
\hline \multirow{3}{*}{ Responsiveness } & \multirow{3}{*}{.862} & \multirow{3}{*}{$0,60-0,79$} & \multirow{3}{*}{$\begin{array}{c}\text { Reabilitas } \\
\text { Baik }\end{array}$} & $\mathrm{Q} 22$ & .768 & 0,207 & Valid \\
\hline & & & & $\mathrm{Q} 23$ & .707 & 0,207 & Valid \\
\hline & & & & Q24 & .750 & 0,207 & Valid \\
\hline
\end{tabular}

Dari tabel diatas menunjukkan hasil kuesioner berjumlah 20 item dan berjumlah 5 variabel diperoleh hasil bahwa untuk uji validitas diketahui bahwa nilai r-hitung kesemuannya yang dihasilkan melebihi r-tabel sebesar 0,207 , oleh karena itu dapat dikatakan seluruh item pernyataan dapat disimpulkan valid, sehingga tidak ada item yang ditolak atau hilang dalam pengujian ini, sedangkan untuk pengujian reabilitas dapat diketahui dari tabel diatas bahwa nilai yang dihasilkan oleh cronbach's alpha tidak ada nilai yang kurang dari 0,60, sehingga dapat disimpulkan variabel assurance, reliability, tangibility, empathy, dan responsiveness, dapat diterima atau dapat dikatakan reliabel.

JURNAL ILMIAH EKONOMI ISLAM VOL. 03 NO. 01, MARET 2017

\section{Hasil Penelitian}

Sebelum dapat melakukan analisis dengan metode Important Performance Analysis dilakukan uji validitas dan reliabilitas instrumen penelitian. Berdasarkan hasil uji validitas dan reliabilitas didapat bahwa semua butir-butir instrumen dari penelitian ini telah dinyatakan valid dan reliabel, sehingga instrumen penelitian tersebut dapat digunakan untuk analisis selanjutnya.

Metode Importance Performance Analysis digunakan untuk melihat sejauh mana tingkat kepuasan nasabah terhadap pelayanan yang telah diberikan oleh petugas bank. Metode analisis yang digunakan adalah 
analisis kuadran. Analisis kuadran merupakan suatu bangun yang dibagi atas empat bagian yang dibatasi oleh dua buah garis yang berpotongan tegak lurus. Untuk menerapkan analisis kuadran yaitu dengan menghitung rata-rata skor kinerja dan kepentingan. ${ }^{25}$. Berdasarkan penghitungan dapat diperhatikan pada tabel di bawah ini :

\begin{tabular}{|c|c|c|c|c|c|}
\hline \multicolumn{6}{|c|}{ Hasil Perhitungan Rata-rata Tingkat Kepentingan dan Kineria Bank } \\
\hline \multirow{2}{*}{\multicolumn{2}{|c|}{ Variabel }} & \multirow{2}{*}{ Pernyataan } & \begin{tabular}{|l} 
Tingkat \\
\end{tabular} & Rata-Rata & Rata-Rata \\
\hline & & & Kesesuaian Tki $(\%)$ & tingkat kepuasan Xi & tingkat kepentingan Y \\
\hline \multirow{4}{*}{ ASSURANCE } & A1 & Karyawan professional & $97.27 \%$ & 3.96 & 4.07 \\
\hline & A2 & Karyawan ramah & $97.09 \%$ & 4.08 & 4.20 \\
\hline & $A 3$ & Ketenangan hati & $94.28 \%$ & 3.84 & 4.08 \\
\hline & A4 & Mudah diakses & $95.78 \%$ & 4.03 & 4.21 \\
\hline \multirow{4}{*}{ RELIABILITY } & R1 & Kemudahan & $90.57 \%$ & 3.73 & 4.12 \\
\hline & R2 & Kecepatan & $91.78 \%$ & 3.60 & 3.92 \\
\hline & $\mathrm{R3}$ & Ketepatan & $94.03 \%$ & 3.68 & 3.91 \\
\hline & R4 & Keamanan & $94.97 \%$ & 3.99 & 4.20 \\
\hline \multirow{3}{*}{ TANGIBLITY } & T1 & Penampilan karyawan rapi & $99.47 \%$ & 4.16 & 4.18 \\
\hline & T2 & \begin{tabular}{|l|} 
Perlengkapan atau peralatan modern \\
\end{tabular} & $96.96 \%$ & 3.90 & 4.02 \\
\hline & T3 & Fasilitas yang sesuai & $98.34 \%$ & 3.94 & 4.01 \\
\hline \multirow{6}{*}{ ЕМРАТНY } & E1 & Perhatian tulus & $92.86 \%$ & 3.61 & 3.89 \\
\hline & E2 & Memahami kebutuhan spesifik & $95.42 \%$ & 3.93 & 4.12 \\
\hline & $E 3$ & Layanan produk yang menguntungkan & $95.03 \%$ & 3.61 & 3.80 \\
\hline & E4 & Biaya layanan yang rendah & $92.53 \%$ & 3.58 & 3.87 \\
\hline & E5 & Beroperasi pada jam yang tepat & $95.40 \%$ & 3.69 & 3.87 \\
\hline & E6 & \begin{tabular}{|l|} 
bkasi yang stategis \\
\end{tabular} & $96.75 \%$ & 3.97 & 4.10 \\
\hline \multirow{4}{*}{ RESPONSIVENESS } & R1 & Kemuuan membantu nasabah. & $95.97 \%$ & 3.97 & 4.13 \\
\hline & R2 & Kejelasan informasi & $94.72 \%$ & 3.79 & 4.00 \\
\hline & R3 & Menganggapi pengaduan atau kelhhan & $95.01 \%$ & 3.81 & 4.01 \\
\hline & & Rata-Rata & $95.21 \%$ & 3.84 & 4.04 \\
\hline
\end{tabular}

\section{Tingkat Kesesuaian}

Tingkat kesesuaian merupakan hasil perbandingan antara menghitung skor kinerja dan skor kepentingan, sehingga tingkat kesesuaian ini yang digunakan untuk menentukan skala prioritas layanan dan prioritas perbaikan mencapai kepuasan pelanggan $^{26}$. Berdasarkan perhitungan Tingkat Kesesuaian (Tki) pada Tabel diatas diperoleh nilai tingkat kesesuaian rata-rata sebesar 95,21\% dengan memiliki rentang nilai yang berada pada kisaran antara $90.57 \%$ sampai dengan 99.47\%. Atribut yang memiliki nilai sebesar $90.57 \%$ adalah kemudahan pelanggan dalam bertransaksi. Hal ini menunjukkan bahwa kemudahan

\footnotetext{
${ }^{25}$ Ibid. Hlm. 241

${ }^{26}$ Yola, M dan Budianto, D. 2013. “Analisis Kepuasan Konsumen Terhadap Kualitas Pelayanan Dan Harga Produk Pada Supermarket Dengan Menggunakan Metode Importance Performance Analysis (IPA)". Jurnal Optimasi Sistem Industri 12 (2):301-309
}

dalam bertransaki yang ada pada Bank Mega, Bank BNI dan Bank Mandiri dirasa masih belum sesuai dengan harapan nasabah sehingga perlu adanya perbaikan dan perhatian dari ketiga Bank tersebut. Atribut yang memiliki nilai $99.47 \%$ adalah penampilan karyawan bank yang rapi. Pada atribut ini menandakan bahwa penampilan karyawan dinilai oleh nasabah sudah sangat sesuai dengan harapan konsumen, akan tetapi masih perlu diperhatikan dan dipertahankan kualitasnya.

Hubungan kesesuaian antara tingkat kepentingan dan tingkat kinerja sangat baik dan sesuai, hal ini didukung dengan pendapat Sudaryanto (2007) jika presentase $80-100 \%$ maka kesesuaian tersebut dapat dikatakan kinerja dari masing-masing atribut telah dapat memenuhi harapan dari konsumen tetapi masih perlu dilakukan perbaikan lagi. Ratarata tingkat kinerja sebesar 3,84 dan rata-rata tingkat kepentingan sebesar 4.04. Nilai ratarata tersebut akan digunakan dalam menentukan diagram kartesius (Importance Performance Analysis) yang dibagi menjadi empat kuadran yang meliputi kuadran I prioritas utama, kuadran II pertahankan prestasi, kuadran III prioritas rendah serta kuadran IV berlebihan.

\section{Penjabaran atribut berdasarkan diagram Importance Performance Analysis}

Diagram kartesius merupakan suatu bangun yang dibagi atas empat bagian yang dibatasi oleh dua buah garis yang berpotongan tegak lurus pada titik-titik (x, y), dimana $\mathrm{x}$ merupakan rata-rata dari skor tingkat pelaksanaan seluruh faktor dan y adalah rata-rata dari rata-rata skor tingkat kepentingan seluruh faktor yang mempengaruhi kepuasan pelanggan, Supranto (2011). Penjabaran kuadran Importance 
Performance Analysis dapat dilihat pada Gambar dibawah ini:

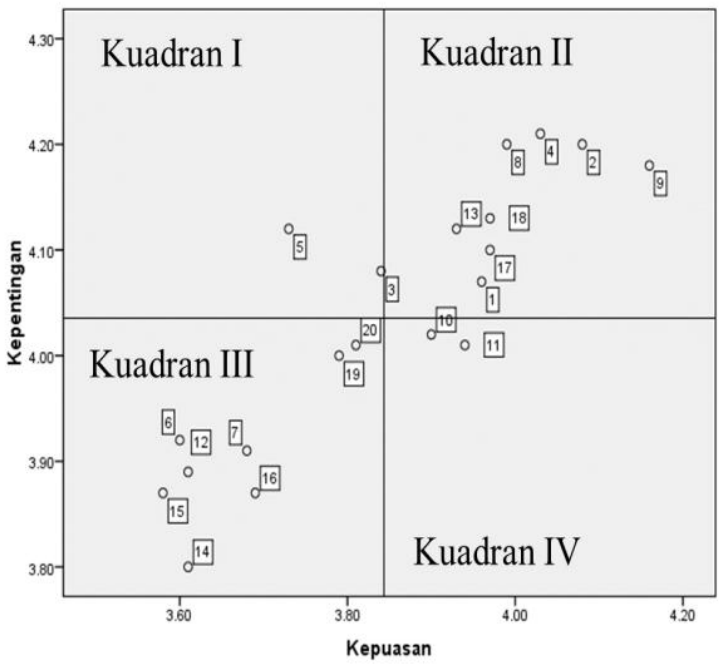

Keterangan:

Adapun letak kuadran tersebut menggambarkan keadaan yang berbeda. Pemetaan berdasarkan tingkat kepentingan dan tingkat kinerja ini memungkinkan pihak Bank untuk segera melakukan perbaikan pada atribut yang dianggap penting oleh nasabah dalam jangka waktu yang relative dekat. Setiap kuadran dijelaskan dengan interpretasi sebagai berikut :

\section{Kuadran I (Prioritas Utama)}

Pada kuadran ini menggambarkan faktorfaktor yang dianggap penting dan diharapkan konsumen, akan tetapi kinerja dari pihak Bank belum memberikan kepuasan terhadap apa yang diharapkan nasabah secara optimal, sehingga membuat nasabah merasa kecewa. Dimensi inilah yang perlu diprioritaskan untuk diperbaiki. Terdapat 2 Atribut yang termasuk pada kuadran I antara lain Ketenangan hati yaitu Bank memiliki karyawan yang dapat dipercaya dan Kemudahan dalam memberikan pelayanan sesuai dengan yang dijanjikan yaitu Ketika nasabah mempunyai masalah, maka pihak bank membantu memecahkan masalah.

\section{Kuadran II (Pertahankan Prestasi)}

Kuadran II merupakan kuadran yang paling diharapkan oleh nasabah, atributatribut tersebut telah sesuai dengan yang dirasakan dan sebagai faktor-faktor yang dianggap penting serta diharapkan sebagai faktor penunjang kepuasan nasabah sehingga perusahaan wajib untuk mempertahankan prestasi kinerja tersebut. Gambar diatas menunjukkan bahwa terdapat 8 atribut yang termasuk dalam kuadran II. Atribut-atribut tersebut antara lain karyawan profesional, karyawan ramah, mudah diakses, keamanan, penampilan karyawan yang rapi, memahami kebutuhan spesifik, lokasi yang straegis, dan kemauan membantu nasabah.

\section{Kuadran III (Prioritas Rendah)}

Kuadran III terdapat faktor-faktor yang dianggap mempunyai tingkat persepsi atau kinerja aktual yang rendah dan tidak terlalu penting atau tidak terlalu diharapkan oleh konsumen sehingga perusahaan tidak perlu memprioritaskan atau memberikan perhatian lebih pada faktor-faktor tersebut. Gambar diatas menunjukkan bahwa terdapat 8 atribut yang termasuk dalam kuadran III. Atribut-atribut tersebut antara lain kecepatan, ketepatan, perhatian tulus, layanan produk yang menguntungkan, biaya layanan yang rendah, beroperasi pada jam yang tepat, kejelasan informasi, dan menanggapi pengaduan dan keluhan.

\section{Kuadran IV (Berlebihan)}

Pada kuadaran ini terdapat faktor-faktor yang dianggap tidak terlalu penting dan tidak terlalu diharapkan oleh pelanggan 
sehingga perusahaan lebih baik mengalokasikan sumber daya yang terkait pada faktor tersebut kepada faktor lain yang lebih memiliki tingkat prioritas lebih tinggi. Gambar diatas menunjukkan bahwa terdapat 2 atribut yang termasuk dalam kuadran IV. Atribut-atribut tersebut antara lain perlengkapan atau peralatan yang modern dan fasilitas yang sesuai.

\section{Perhitungan berdasarkan Customer Satisfacttion Indeks (CSI)}

Customer Satisfacton Index digunakan untuk mengetahui tingkat kepuasan pengunjung secara menyeluruh dengan melihat tingkat kepentingan dari atributatribut produk/jasa. Hasil dari perhitungan nilai tersebut dapat disajikan dalam tabel dibawah ini:

\begin{tabular}{|c|c|c|c|c|c|}
\hline \multicolumn{6}{|c|}{ Hasil Perhitungan CSI (Customer Satisfaction Indeks) Tingkat Kepentingan dan Kinerja Bank } \\
\hline \multicolumn{2}{|l|}{ Variabel } & Pernyataan & $\begin{array}{c}\text { Rata-Rata } \\
\text { tingkat kepuasan X }\end{array}$ & $\begin{array}{c}\text { Rata-Rata } \\
\text { tingkat kepentingan } \mathrm{Yi}\end{array}$ & $\operatorname{SCORE}(\mathrm{S})$ \\
\hline \multirow{4}{*}{ ASSURANCE } & A1 & Karyawan professional & 3.96 & 4.07 & 16.09 \\
\hline & A2 & Karyawan ramah & 4.08 & 4.20 & 17.13 \\
\hline & A3 & Ketenangan hati & 3.84 & 4.08 & 15.68 \\
\hline & A4 & Mudah diakses & 4.03 & 4.21 & 16.98 \\
\hline \multirow{4}{*}{ RELIABILITY } & R1 & Kemudahan & 3.73 & 4.12 & 15.39 \\
\hline & R2 & Kecepatan & 3.60 & 3.92 & 14.12 \\
\hline & R3 & Ketepatan & 3.68 & 3.91 & 14.38 \\
\hline & R4 & Keamanan & 3.99 & 4.20 & 16.75 \\
\hline \multirow{3}{*}{ TANGIBILITY } & T1 & Penampilan karyawan rapi & 4.16 & 4.18 & 17.36 \\
\hline & $\mathrm{T} 2$ & Perlengkapan atau peratatan modern & 3.90 & 4.02 & 15.69 \\
\hline & $\mathrm{T} 3$ & Fasilitas yang sesuai & 3.94 & 4.01 & 15.82 \\
\hline \multirow{6}{*}{ EMPATHY } & E1 & Perhatian tulus & 3.61 & 3.89 & 14.04 \\
\hline & $\mathrm{E} 2$ & Memahami kebutuhan spesifik & 3.93 & 4.12 & 16.21 \\
\hline & E3 & Layanan produk yang menguntungkan & 3.61 & 3.80 & 13.72 \\
\hline & E4 & Biaya layanan yang rendah & 3.58 & 3.87 & 13.83 \\
\hline & E5 & Beroperasi pada jam yang tepat & 3.69 & 3.87 & 14.26 \\
\hline & E6 & \begin{tabular}{|l|} 
lokasi yang stategis \\
\end{tabular} & 3.97 & 4.10 & 16.26 \\
\hline \multirow{4}{*}{ RESPONSIVENESS } & R1 & Kemauan membantu nasabah. & 3.97 & 4.13 & 16.40 \\
\hline & $\mathrm{R} 2$ & Kejelasan informasi & 3.79 & 4.00 & 15.16 \\
\hline & $\mathrm{R} 3$ & Menganggapi pengaduan atau keluhan & 3.81 & 4.01 & 15.29 \\
\hline & & Rata-Rata & 76.87 & & 310.57 \\
\hline \multicolumn{3}{|c|}{ Hasil Perhitungan CSI (Customer Satisfaction Indeks) } & \multicolumn{3}{|c|}{$80.80 \%$} \\
\hline
\end{tabular}

Setelah dilakukan penelitian dan dilakukan perhitungan CSI, diketahui bahwa nilai CSI yang dihasilkan dari penelitian ini adalah $80.80 \%$. Hal ini menunjukkan bahwa kepuasan Bank yang terdiri dari Bank Mega, Bank BNI, dan Bank Mandiri secara keseluruhan dapat dikatakan Puas. Kepuasan nasabah ini didasarkan pada tabel Interpretasi Customer Satisfaction Index diatas dalam Fitriana, et,al (2014) yang menunjukkan bahwa nilai CSI yang diperoleh pada JURNAL ILMIAH EKONOMI ISLAM VOL. 03 NO. 01, MARET 2017 penelitian ini berada pada kisaran 66\% 80,99\%. Hal ini menunjukkan bahwa kinerja Bank sudah hampir mencapai harapan nasabah, sehingga nasabah banyak yang merasa puas dengan pelayanan yang telah diberikan oleh pihak bank di Surakarta. Ketika kinerja sesuai dengan harapan maka penumpang akan merasa puas, dan ketika kinerja melebihi harapan maka penumpang akan merasa sangat puas. Harapan pelanggan ini dapat terbentuk oleh pengalaman masa lampau, komentar dari kerabatnya serta janji dan informasi dari Bank sendiri maupun pesaing.

\section{Penutup}

Berdasarkan hasil penelitian dapat disimpulkan bahwa atribut yang perlu diperhatikan dan menjadi prioritas utama untuk dilakukan perbaikan adalah kuadran I yaitu Ketenangan hati yaitu Bank memiliki karyawan yang dapat dipercaya dan Kemudahan dalam memberikan pelayanan sesuai dengan yang dijanjikan yaitu Ketika nasabah mempunyai masalah, maka pihak bank membantu memecahkan masalah. Selanjutnya perhitungan menggunakan tingkat kesesuaian nilai kualitas pelayanan terhadap kepuasan nasabah bank mencapai nilai $95,21 \%$. Nilai tersebut berada pada rentang $80-100 \%$, dengan demikian secara keseluruhan nasabah merasa puas terhadap kinerja pelayanan bank di Surakarta. Hal itu juga dapat diperlihatkan dari hasil perhitungan CSI yang menghasilkan nilai sebesar $80.80 \%$, yang menandakan bahwa pelayanan yang diberikan oleh pihak bank yang terdiri dari Bank Mega, Bank BNI dan Bank Mandiri terhadap kepuasan nasabah dirasa puas oleh pihak nasabah. 


\section{Daftar Pustaka}

Astuti, Septin Puji, et, al.,, 2009, "Meningkatkan Kualitas Pelayanan di Bank Syariah; Penelitian dengan Fuzzy Servqual dan Dimensi Carter", Jurnal Manajemen Bisnis Vol. 2 No. 1 April-Juli 2009 (47-58).

Azzahra Handriati, Annisa., dkk, 2015, "Analisis Kualitas Pelayanan Publik Terhadap Kepuasan Konsumen Dengan Menggunakan Metode Servperf-Ipa-Csi", Teknoin Vol. 21 No. 4 Desember 2015 : 178-190

Dharmayanti, Diah. 2006. "Analisis Dampak Service Performance Dan Kepuasan Sebagai Moderating Variable Terhadap Loyalitas Nasabah". Jurnal Manajemen Pemasaran, Vol. 1, No. 1, April 2006: 3543

Ghozali, 2005. "Aplikasi Analisis Multivarariate Dengan Program SPSS". Badan Penerbit Universitas Diponegoro Semarang. Semarang.

Harish, M. Azka, et, al.,. 2014. "Usulan Perbaikan Kualitas Pelayanan Menggunkan Dimensi Banking Service Quality dengan Metode Service Quality (Studi Kasus di Bank X)". Jurnal Online Institut Teknologi Nasional. No. 04. Vol. 2. Hlm. 121-131

Hartanto, Juzan Tri. 2010. "Analisis Pengaruh Kualitas Pelayanan Jasa Perbankan Terhadap Kepuasan Nasabah (Study Kasus Pada PD. BPR Bank Jogja)". Program Magister Manajemen Universitas Gunadarma

Hasan, Ali. 2010. "Marketing Bank Syariah Cara Jitu Meningkatkan Pertumbuhan Pasar Bank Syariah". Ghalia Indonesia. Bogor.

Hasan, M. Iqbal. 2002, "Pokok-Pokok Materi Metodologi Penelitian dan Aplikasinya", Cetakan Pertama, Ghalia Indonesia, Jakarta.

Husna Ainu Syukri, Siti., 2014, "Penerapan Customer Satisfaction Index (Csi) Dan Analisis Gap Pada Kualitas Pelayanan
Trans Jogja", Jurnal Ilmiah Teknik Industri, Vol. 13, No. 2, Des 2014

Indra Maiyanti, Sri., Irmeilyana,Verawaty, "Aplied Customer Satisfaction Index (CSI) and Importance- Performance Analysis (IPA) to know Student Satisfaction Level of Sriwijaya University Library Services".

Maulana, Yassyir, dkk. 2012. "Analisis Pengaruh Servqual Terhadap Kepuasan Serta Loyalitas Mahasiswa (Studi Kasus Pada Jurusan Teknik Mesin Di Universitas "XYZ”)”. Jurnal Miller, Cyndee 1993. "Moving Production to Services". New Jersey: Englewood Prentice-Hall, Inc. Rekayasa Mesin Vol.3, No. 1 Tahun 2012: 258-267

Oscar Ong, Johan dan Pambudi, Jati.2014. "Analisis Kepuasan Pelanggan Dengan Importance Performance Analysis Di Sbu Laboratory Cibitung Pt Sucofindo (Persero)". Undip, Vol IX, No 1, Januari 2014

Sangadji, Etta Mamang dan Sopiah. 2013. "Perilaku konsumen". CV. Andi Offset. Yogyakarta.

Supranto, J. 1997. "Analisis Multivariat Arti dan Interpretasi". Jakarta: Rineka Cipta

Statistik Perbankan Indonesia - Vol. 14, No. 1, Desember 2015 (www.ojk.go.id).

Tho'in, Muhammad. 2011. Pengaruh Faktorfaktor Kualitas Jasa terhadap Kepuasan Nasabah di Baitul Maal wat Tamwil (BMT) Tekun Karanggede Boyolali. Muqtasid Jurnal Ekonomi dan Perbankan Syariah STAIN Salatiga. Vol. 2, Juli 7389.

Tho'in, Muhammad. 2016. Kompetensi Sumber Daya Bank Syariah Berdasarkan Prinsip-prinsip Syariah Islam (Studi Kasus Pada BNI Syariah di Surakarta). Jurnal Ilmiah Ekonomi Islam, LPPM STIE AAS Surakarta. Vol. 2 No. 3, November 158171.

Tjiptono, Fandy dan Anastasia Diana. 1998. "Total Quality Management". Andi. Yogyakarta. 
Kualitas Pelayanan Bank Dengan Menggunakan Metode IPA

Tjiptono, Fandy 2000. "Prinsip-prinsip Total Quaiity Service". CV. Andi Offset.Yogyakarta

Wijaya, Tony. 2011. "Manajemen Kualitas Jasa". Indeks. Jakarta

Yola, M dan Budianto, D. 2013. "Analisis Kepuasan Konsumen Terhadap Kualitas Pelayanan Dan Harga Produk Pada Supermarket Dengan Menggunakan Metode Importance Performance Analysis (IPA)". Jurnal Optimasi Sistem Industri 12 (2):301-309 